\title{
Neutrophil Recruitment in Clostridium difficile Toxin A Enteritis in the Rabbit
}

\author{
Ciaran P. Kelly, Scott Becker, Joanne K. Linevsky, Manher A. Joshi, J. Conor O'Keane,” \\ Burton F. Dickey, * J. Thomas LaMont, and Charalabos Pothoulakis \\ Section of Gastroenterology and the *Pulmonary Center, Evans Memorial Department of Clinical Research; \\ and ${ }^{\ddagger}$ Mallory Institute of Pathology, Boston University School of Medicine, Boston, Massachusetts 02118
}

\begin{abstract}
Neutrophil infiltration is a prominent feature of Clostridium difficile-associated enteritis and colitis. The aim of this study was to examine the importance of neutrophil recruitment and neutrophil-mediated tissue damage in $C$. difficile toxin A-induced enteritis. Competitive binding experiments using purified ${ }^{3} \mathbf{H}$-toxin $A$ demonstrated the presence of a single class of medium affinity receptors on rabbit neutrophils $\left(K_{d} 7 \times 10^{-8}\right.$ $M)$. Pertussis toxin and the nonhydrolyzable GTP analog GTPgamma $\mathrm{S}$ both inhibited ${ }^{3} \mathrm{H}$-toxin $\mathrm{A}$ binding (by 56 and $65 \%$, respectively), indicating that the rabbit neutrophil toxin A receptor is $\mathbf{G}$ protein linked. Toxin $A$ elicited a dose-dependent $(25-200 \mu \mathrm{g} / \mathrm{ml})$ stimulation of neutrophil migration in vitro, and this functional effect was also pertussis toxin sensitive (69\% inhibition). Treatment of neutrophils with R15.7, a blocking monoclonal antibody to the leukocyte adhesion molecule CD18, inhibited toxin A-stimulated neutrophil migration by $85 \%$ in vitro. Pretreatment of rabbits with R15.7 also prevented neutrophil infiltration of toxin A-exposed ileal loops in vivo as determined by histologic examination and by ileal tissue myeloperoxidase levels. Furthermore, R15.7 effected a substantial inhibition of fluid secretion (by $65 \%$ ), mannitol permeability (by 66\%), and histologic damage in toxin A-exposed ileal loops. Anti-CD18 (R15.7) had no inhibitory effect on cholera toxin enterotoxicity. These data demonstrate that $C$. difficile toxin $A$ is a proinflammatory toxin whose enterotoxic effects are substantially dependent upon neutrophil recruitment. (J. Clin. Invest. 1994. 93:1257-1265.) Key words: enterotoxin - toxin receptor $\bullet \mathbf{G}$ protein • adhesion molecule • intestinal inflammation
\end{abstract}

\section{Introduction}

Antibiotic-induced Clostridium difficile colitis is associated with a prominent influx of neutrophils into the colonic mucosa (1). Its most severe form, pseudomembranous colitis, is characterized by a dense acute inflammatory infiltrate with microabcesses and surface plaques or pseudomembranes rich in neutrophils (2). The acute enteritis induced by $C$. difficile appears to be mediated largely, if not entirely, by a $308-\mathrm{kD}$ protein exotoxin, toxin A (3-6). Exposure of rabbit ileal loops to toxin A results in a profound inflammatory response with epi-

Address correspondence to Ciaran P. Kelly, Evans 201, Gastroenterology, Boston University Medical Center, The University Hospital, 88 East Newton Street, Boston, MA 02118.

Received for publication 8 April 1993 and in revised form 9 November 1993.

J. Clin. Invest.

(C) The American Society for Clinical Investigation, Inc.

0021-9738/94/03/1257/09 \$2.00

Volume 93, March 1994, 1257-1265 thelial cell necrosis and dehiscence and massive infiltration of the mucosa by neutrophils, findings analagous to those seen in human $C$. difficile colitis. Increased release of leukotriene $\mathbf{B}_{4}$ and exudation of plasma proteins into the lumen are evident in toxin A-exposed loops and have been attributed to the presence of activated neutrophils in the ileal segment $(6,7)$. These toxin A effects are in contrast to cholera toxin or Escherichia coli enterotoxin which elicit secretion of water from the ileum without an associated marked inflammatory response $(7,8)$.

We reported previously that toxin A stimulated a rapid, transient rise in cytosolic calcium in human neutrophils in vitro (9). This effect was inhibited by preincubation of neutrophils with pertussis toxin. Since pertussis toxin inactivates guanine nucleotide-binding proteins, these findings suggest that toxin A stimulation of neutrophils is mediated via a $G$ proteindependent mechanism (10). We have also shown that toxin A is chemotactic to human neutrophils (9) and stimulates cytokine release from macrophages in vitro (11). These findings lead us to hypothesize that the ability of toxin A to directly activate inflammatory cells may underlie its potent proinflammatory effects in vivo.

In this study we demonstrate a specific surface receptor for C. difficile toxin A on the rabbit neutrophil and present additional data to indicate that this receptor is directly coupled to a $G$ protein. Furthermore, we show that toxin A-stimulated neutrophil migration is pertussis toxin sensitive, again indicating coupling of the toxin A receptor to one of the $G_{i}$ guanine nucleotide-binding proteins known to be present in neutrophils (12-14). Finally, the in vivo importance of neutrophil recruitment in toxin A-induced enteritis is demonstrated by substantial inhibition of enterotoxicity when neutrophil infiltration is blocked using a monoclonal antibody directed against the leukocyte adhesion molecule CD18.

\section{Methods}

Toxin A purification and radiolabeling. Toxin A was purified, as previously described, from broth culture supernatants of $C$. difficile strain $10463(6,15,16)$. Enterotoxicity of purified toxin A was confirmed in the ligated rabbit ileal loop assay (6), and cytotoxicity was determined by cell rounding of IMR-90 fibroblasts and rat basophilic leukemia cells (17). The minimum dose of toxin A which results in demonstrable enterotoxicity at $5 \mathrm{~h}$ in the rabbit ileal loop assay is $\sim 1 \mu \mathrm{g}$. The minimum effective dose of toxin A in the 24-h cytotoxicity assay is $\sim 10 \mathrm{ng} / \mathrm{ml}$. The toxin A preparations used in this study contained a single band at $\sim 300 \mathrm{kD}$ on SDS-PAGE and migrated as a single peak on an HPLC SW300 molecular sieve column (Phenomenex Inc., Torrance, CA). Purified toxin A was ${ }^{3} \mathrm{H}$-labeled using Bolton-Hunter reagent ( $N$-succinimidyl $\left[2,3-{ }^{3} \mathrm{H}\right]$ propionate $)$ as previously described by us (18). Radiolabeled toxin A migrated identically to native toxin on both SDS-PAGE and HPLC and retained full cytotoxic and enterotoxic activity.

Binding of ${ }^{3} \mathrm{H}$-toxin A to intact neutrophils. Peritoneal neutrophils were obtained from male New Zealand White rabbits 10-14 h after intraperitoneal instillation of $250 \mathrm{ml}$ of $0.1 \%$ oyster glycogen (Sigma Immunochemicals, St. Louis, $\mathrm{MO}$ ) in $0.9 \% \mathrm{NaCl}$ (19). The peritoneal 
exudates were collected in modified Hanks' solution (Cellgro-Mediatech, Inc., Herndon, VA) at $4^{\circ} \mathrm{C}$ and were subjected to Ficoll-Hypaque (Pharmacia LKB Biotechnology Inc., Piscataway, NJ) centrifugation followed by hypotonic lysis. Neutrophil numbers were determined using a hemacytometer, and cells were resuspended in modified Hanks' at a concentration of $10^{8}$ cells per milliliter. Peritoneal exudates processed in this manner yielded $>95 \%$ neutrophils as determined by light microscopy with Wright's stain and were $>95 \%$ viable as measured by trypan blue exclusion.

Experiments were performed in 1.8-ml Eppendorf tubes precoated with $5 \%$ skim milk in $50 \mathrm{mM}$ Tris with $0.2 \mathrm{M} \mathrm{NaCl}(\mathrm{pH} 7.4)$ to reduce nonspecific binding of toxin A. ${ }^{3} \mathrm{H}$-toxin $\mathrm{A}(220 \mathrm{ng}, \sim 160,000 \mathrm{dpm})$ was added to tubes containing $10^{7}$ neutrophils in a total volume of 0.2 $\mathrm{ml}$ of modified Hanks' solution ( $\mathrm{pH} 7.4$ ) to yield a final ${ }^{3} \mathrm{H}$-toxin $\mathrm{A}$ concentration of $3.6 \mathrm{nM}$. Unlabeled toxin A was added in some experiments to achieve a final concentration of $0.05-5 \mu \mathrm{M}$, and cells were incubated at $4^{\circ} \mathrm{C}$ for $60 \mathrm{~min}$. Additional Hanks' buffer $(1 \mathrm{ml}$ ) was then added, and tubes were centrifuged at $11,000 \mathrm{~g}$ for $3 \mathrm{~min}$ to remove unbound ligand. Pellets were washed twice with $1 \mathrm{ml}$ of ice cold Hanks' buffer and were dissolved in $0.3 \mathrm{ml}$ of buffer containing 10\% SDS. Dissolved cells were transferred to $7-\mathrm{ml}$ scintillation vials and were counted for radioactivity. Specific binding was taken as the difference in ${ }^{3} \mathrm{H}$-toxin $\mathrm{A}$ binding in the presence or absence of 100 -fold excess of unlabeled toxin A. Background radioactivity in tubes containing no cells and incubated with ${ }^{3} \mathrm{H}$-toxin $\mathrm{A}$ was always subtracted and accounted for $\sim 1 \%$ of added radioactivity. The apparent $K_{\mathrm{d}}$ of binding and the maximum binding activity (binding sites per cell) were calculated by Scatchard plot analysis using the weighted least-squares-fit IBM computer program Ligand as described by Munson (20), in which nonspecific binding is treated as a fitted parameter from a weighted analysis of the binding data.

To determine the effect of pertussis toxin on ${ }^{3} \mathrm{H}$-toxin $\mathrm{A}$ binding to intact neutrophils, cells were preincubated with pertussis toxin (Calbiochem-Novabiochem Corp., San Diego, CA) at a concentration of $500 \mathrm{ng} / \mathrm{ml}$ for $90 \mathrm{~min}$ at $37^{\circ} \mathrm{C}$. Cells were then rinsed twice with $1 \mathrm{ml}$ of modified Hanks' solution, were resuspended in the same solution, and ${ }^{3} \mathrm{H}$-toxin A binding was assayed as described above.

Binding of ${ }^{3} \mathrm{H}$-toxin A to purified neutrophil membranes. Rabbit neutrophil plasma membrane preparations were purified according to the method of Maeda et al. (21). The degree of membrane purification was 15 -fold as determined by leukocyte alkaline phosphatase activity measured using a commercially available colorimetric assay (Sigma Immunochemicals). Studies on the binding of ${ }^{3} \mathrm{H}$-toxin A to rabbit neutrophil membranes were performed using methods identical to those described above for intact neutrophils, except that 230- $\mu$ l polyallomer tubes (Beckman Instruments, Inc., Palo Alto, CA) were used, each tube contained $0.1 \mathrm{mg}$ of purified membrane and, after incubation, unbound ligand was removed by centrifugation at $40,000 \mathrm{rpm}$ for $10 \mathrm{~min}$.

The effect of GTP, ATP, and their analogues on binding of toxin A to purified neutrophil membranes was determined by preincubating membranes ( $100 \mu \mathrm{g} /$ tube) with GTP (Sigma Immunochemicals), GTPgamma S (guanosine 5'-O-3-thiotriphosphate; Boehringer Mannheim Corp., Indianapolis, IN), Gpp(NH)p (5'-guanylylimidodiphosphate; Sigma Immunochemicals), GDPbeta S (Sigma Immunochemicals), ATP (Sigma Immunochemicals), and App(NH)p (5'-adenylylimidodiphosphate; Sigma Immunochemicals), each at a concentration of $100 \mu \mathrm{M}$ for $15 \mathrm{~min}$ at $22^{\circ} \mathrm{C}$ in $50 \mathrm{mM}$ Tris buffer ( $\mathrm{pH} \mathrm{7.4,} \mathrm{final}$ volume of $200 \mu \mathrm{l}$ ). After incubation, tubes were transferred to $4^{\circ} \mathrm{C}$, and specific ${ }^{3} \mathrm{H}$-toxin $\mathrm{A}$ binding was assayed as described above.

Toxin A-stimulated neutrophil migration. Purified toxin A at concentrations of $12.5-200 \mu \mathrm{g} / \mathrm{ml}$ in Dulbecco's PBS (DPBS; ${ }^{1}$ CellgroMediatech, Inc.) was placed in the lower chambers of a multiwell chemotaxis assembly (NeuroProbe, Cabin John, MD). Rabbit peritoneal

1. Abbreviations used in this paper: DPBS, Dulbecco's PBS; MPO, myeloperoxidase. neutrophils, isolated as described above and suspended in HBSS with calcium and magnesium (Cellgro-Mediatech, Inc.) at a concentration of $5 \times 10^{6} \mathrm{cells} / \mathrm{ml}$, were placed in the upper chambers. The two chambers were separated by a $3-\mu \mathrm{m}$ nitrocellulose filter (Sartorius Filters, Inc., Burlingame, CA). After 1 -h incubation at $37^{\circ} \mathrm{C}$, the filters were removed, placed on glass slides, fixed with ethanol, and stained with hematoxylin. Neutrophil migration was quantified by counting the number of neutrophils migrating a fixed distance into the filter (mean of three high power fields). This distance was arbitrarily set at a point to which 5-10 neutrophils per high power field migrated in response to DPBS, and results are expressed as a mean percentage of migration to DPBS alone. Bacterial endotoxin ( E. coli 055:B5 lipopolysaccharide; Sigma Immunochemicals) $1-100 \mu \mathrm{g} / \mathrm{ml}$ in DPBS was used as a positive control.

In some experiments rabbit neutrophils were preincubated with pertussis toxin (as described above) before migration assays. Pertussis toxin-treated neutrophils were also used as the control for these experiments. Neutrophils were also preincubated $\left(60 \mathrm{~min}\right.$ at $\left.37^{\circ} \mathrm{C}\right)$ with saturating concentrations $\left(50 \mu \mathrm{g} / \mathrm{ml}\right.$ ) of either $R 15.7$, a murine $\mathrm{IgG}_{1}$ monoclonal antibody which binds adhesion epitopes on the common CD18 (beta ${ }_{2}$-integrin) chain of the leukocyte CD11/CD18 adhesion complex (22-24), or with MOPC-21, an irrelevant murine $\mathrm{IgG}_{1}$ monoclonal antibody control (Sigma Immunochemicals). R15.7 was supplied by Dr. Robert Rothlein (Boehringer Ingelheim Ltd., Ridgefield, CT). Toxin A at a concentration of $100 \mu \mathrm{g} / \mathrm{ml}$ was used as chemoattractant for studies using pertussis toxin, R15.7, and MOPC-21.

Toxin A-induced neutrophil recruitment in vivo. Fasting New Zealand White rabbits were anesthetized by intramuscular injection of ketamine $(35 \mathrm{mg} / \mathrm{kg}$ ) and xylozine $(5 \mathrm{mg} / \mathrm{kg})$. Laparotomy was performed, the renal pedicles were tied, and $\left[{ }^{3} \mathrm{H}\right]$ mannitol $(100 \mu \mathrm{Ci}$; New England Nuclear, Boston, MA) was administered intravenously. Some animals also received the anti-CD18 monoclonal antibody R15.7 (2 $\mathrm{mg} / \mathrm{kg}$, i.v.) or MOPC-21, the murine $\mathrm{IgG}_{1}$ monoclonal control (2 $\mathrm{mg} / \mathrm{kg}$, i.v.). Closed ileal loops $(7 \mathrm{~cm})$ were formed and were injected with $1 \mathrm{ml}$ of $50 \mathrm{mM}$ Tris ( $\mathrm{pH} \mathrm{7.4)} \mathrm{or} \mathrm{with} \mathrm{Tris} \mathrm{buffer} \mathrm{containing} 20 \mu \mathrm{g}$ of purified $C$. difficile toxin A or $20 \mu \mathrm{g}$ of Vibrio cholera toxin (Calbiochem-Novabiochem Corp.). Cholera toxin was used as a noninflammatory enterotoxin control (7). The abdominal incision was then closed, and light anesthesia was maintained with sodium pentobarbital ( $10 \mathrm{mg} / \mathrm{kg}$ per hour, i.v.). The animals were killed after $5 \mathrm{~h}$, and the ileal loops were immediately harvested. Loop weight and length were first measured. Total loop mannitol excretion was then established by measuring radioactivity in the luminal fluid. Mannitol excretion per centimeter of loop was expressed as a ratio of mannitol excretion per centimeter in a control loop from the same animal.

Myeloperoxidase (MPO) levels, a measure of neutrophil infiltration, were assayed in aliquots of ileal tissue according to a modification of the method of Bradley et al. (25). Tissue samples were homogenized in the presence of $0.5 \%$ hexadecyltrimethylammonium bromide in $\mathbf{5 0}$ $\mathrm{mM} \mathrm{KH}_{2} \mathrm{PO}_{4}(\mathrm{pH} 6)$, freeze thawed three times, sonicated for $10 \mathrm{~s}$, and centrifuged at $40,000 \mathrm{~g}$ for $15 \mathrm{~min}$. MPO activity in the supernatant was measured in triplicate by a microplate colorimetric assay in which $10 \mu \mathrm{l}$ of sample was mixed with $240 \mu \mathrm{l}$ of $50 \mathrm{mM}$ phosphate buffer containing $0.167 \mathrm{mg} / \mathrm{ml}$ o-dianisidine dihydrochloride (Sigma Immunochemicals) and $0.0005 \%$ hydrogen peroxide ( $\mathrm{pH} 6.0$ ). Color development was read at $460 \mathrm{~nm}$ after $10 \mathrm{~min}$, and results were expressed in MPO units per gram of tissue by comparison with a standard curve derived from parallel assay of purified human MPO (Calbiochem-Novabiochem Corp.).

Ileal tissue samples were also fixed in formalin, were paraffin embedded, and sections were stained with hematoxylin and eosin. All sections were examined by a single, blinded histopathologist (JCO'K). The histologic severity of enteritis was graded in each ileal tissue section, taking into account the following features: $(a)$ neutrophil margination and tissue infiltration; $(b)$ hemorrhagic congestion and edema of the mucosa; and $(c)$ epithelial cell damage. A score of $0-3$, denoting increasingly severe abnormality, was assigned to each of these parameters. 
Statistical analyses. Statistical analyses were performed using the GB-STAT professional statistics software program (Dynamic Microsystems Inc., Baltimore, MD). ANOVA with protected $t$ tests was used for intergroup comparisons, except for the histologic grades, where a nonparametric test (Wilcoxon signed rank) was used.

\section{Results}

Binding of ${ }^{3} \mathrm{H}$-toxin $\mathrm{A}$ to intact rabbit neutrophils. ${ }^{3} \mathrm{H}$-toxin $\mathrm{A}$ bound specifically to intact rabbit neutrophils (Fig. 1). Competitive binding studies and Scatchard plot analysis showed the presence of a single class of toxin A receptors (Fig. 1, inset) with $K_{\mathrm{d}}$ of $7 \times 10^{-8} \mathrm{M}$ and a maximum binding capacity of 37,000 binding sites per cell. We previously reported that toxin A stimulated a transient increase in cytosolic $\left[\mathrm{Ca}^{2+}\right]_{\mathrm{i}}$ in human neutrophils and that this effect was inhibited by preincubation of neutrophils with pertussis toxin (9). Since pertussis toxin catalyzes the ADP-ribosylation of the guanine nucleotide regulatory proteins $G_{i 2}$ and $G_{i 3}$, these findings suggest that the human neutrophil toxin $A$ receptor is coupled to $a G_{i}$ protein. Thus we examined whether ${ }^{3} \mathrm{H}$-toxin $\mathrm{A}$ binding to intact rabbit neutrophils was also pertussis toxin sensitive. The specific binding of ${ }^{3} \mathrm{H}$-toxin A was inhibited by $56 \%$ (mean value of three experiments, each with triplicate determinations) after exposure of neutrophils to $500 \mathrm{ng} / \mathrm{ml}$ of pertussis toxin for $90 \mathrm{~min}$ at $37^{\circ} \mathrm{C}$. Competetive binding studies with Scatchard plot analysis demonstrated that pertussis toxin-treated neutrophils showed a 20 -fold reduction in the binding dissociation constant of the toxin A receptor $\left(K_{\mathrm{d}} 3.1 \times 10^{-7}\right)$. Pertussis toxin treatment also altered the number of available binding sites for toxin A, which increased approximately threefold to 131,000 sites per cell.

Effect of nucleotides on equilibrium ${ }^{3} \mathrm{H}$-toxin $\mathrm{A}$ binding to neutrophil membranes. Further evidence to indicate coupling of the neutrophil cell-surface toxin A receptor to an endogenous $G$ protein was obtained by measuring specific binding of ${ }^{3} \mathrm{H}$-toxin A to rabbit neutrophil cell membranes in the presence of GTP and the nonhydrolyzable GTP analogues GTPgamma
Table I. Effect of Nucleotides on ${ }^{3} H$-Toxin A Binding to Rabbit Neutrophil Membranes

\begin{tabular}{lccc}
\hline \multicolumn{1}{c}{ Nucleotide } & $n$ & ${ }^{3}$ H-Toxin A bound & $\begin{array}{c}\text { Inhibition of } \\
\text { specific binding }\end{array}$ \\
\hline \multicolumn{1}{c}{$100 \mu M$} & & $p m o l / m g$ & $\%$ \\
Control & 19 & $0.53 \pm 0.02$ & \\
GTP gamma S & 6 & $0.19 \pm 0.03^{*}$ & 65 \\
Gpp(NH)p & 3 & $0.39 \pm 0.01^{*}$ & 28 \\
GTP & 4 & $0.42 \pm 0.05^{\ddagger}$ & 20 \\
GDP beta S & 4 & $0.53 \pm 0.04$ & 2 \\
ATP & 4 & $0.46 \pm 0.07$ & 13 \\
App(NH)p & 4 & $0.56 \pm 0.03$ & 0 \\
\hline
\end{tabular}

Purified rabbit neutrophil cell membranes ( $100 \mu \mathrm{g} /$ tube) were incubated with the nucleotides for $15 \mathrm{~min}$ at $37^{\circ} \mathrm{C}$. Specific binding of ${ }^{3} \mathrm{H}$-toxin A (at a concentration of $120 \mathrm{ng}$ per $0.2 \mathrm{ml}$ ) was then determined as described in Methods and is expressed as picomoles of ${ }^{3} \mathrm{H}$-toxin $\mathrm{A}$ bound per milligram of membrane protein (mean $\pm \mathrm{SE}$, ${ }^{*} P<0.01$ and ${ }^{\ddagger} P<0.05$ in comparison with control).

S and $\mathrm{Gpp}(\mathrm{NH}) \mathrm{p}$. GDPbeta S was used as a nonphosphorylable diphosphonucleotide analogue. To determine the specificity of guanine nucleotides in reducing ligand binding, we also tested the effects of ATP and the nonhydrolyzable ATP analogue $A p p(N H) p$ on ${ }^{3} \mathrm{H}$-toxin A binding. The results of these studies are summarized in Table I. Binding of ${ }^{3} \mathrm{H}$-toxin $\mathrm{A}$ to neutrophil membranes was inhibited by 65 and $28 \%$ by GTPgamma S and $\mathrm{Gpp}(\mathrm{NH}) \mathrm{p}$, respectively, consistent with uncoupling of the toxin A receptor from a signal transducing $G$ protein. GTP inhibited ${ }^{3} \mathrm{H}$-toxin $\mathrm{A}$ binding to a lesser extent (20\%). GDP beta S, ATP, and App (NH)p had no significant effect. These findings provide further evidence that the rabbit neutrophil toxin A receptor is directly linked to a GTP binding protein.

Toxin A-stimulated neutrophil migration. Toxin A stimulated the migration of rabbit neutrophils in a dose-dependent

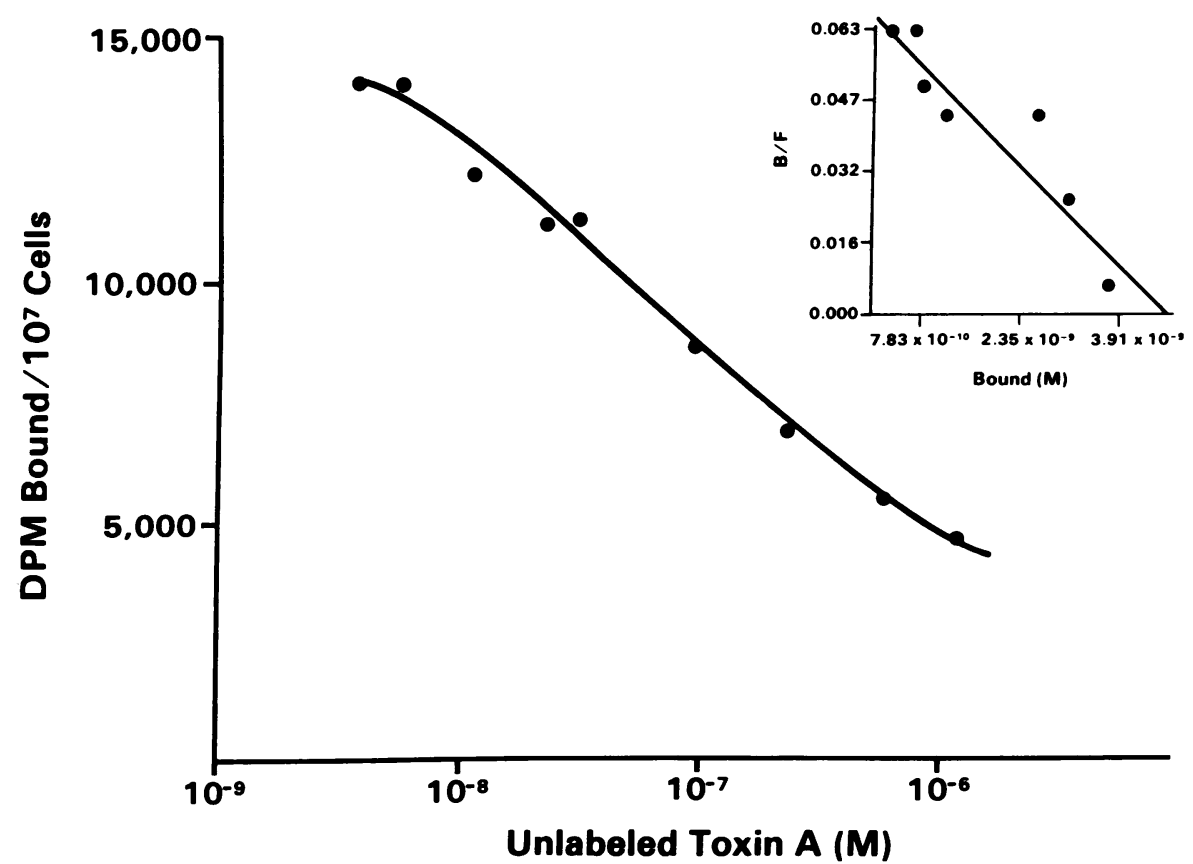

Figure 1. Competitive inhibition of binding of ${ }^{3} \mathrm{H}$-toxin $\mathrm{A}$ to rabbit neutrophils by unlabeled toxin A. Neutrophils $\left(10^{7}\right)$ were incubated with $220 \mathrm{ng}{ }^{3} \mathrm{H}$-toxin A $(160,000$ $\mathrm{dpm}$ ) and increasing doses of unlabeled toxin $\mathrm{A}$ for $60 \mathrm{~min}$ at $4^{\circ} \mathrm{C}$ in $0.2 \mathrm{ml}$ of modified Hanks' solution ( $n=4$ for each group). The final concentration of ${ }^{3} \mathrm{H}$-toxin A was $3.6 \mathrm{nM}$. Specific binding was determined as described in Methods. The inset shows a Scatchard plot of the binding data. 


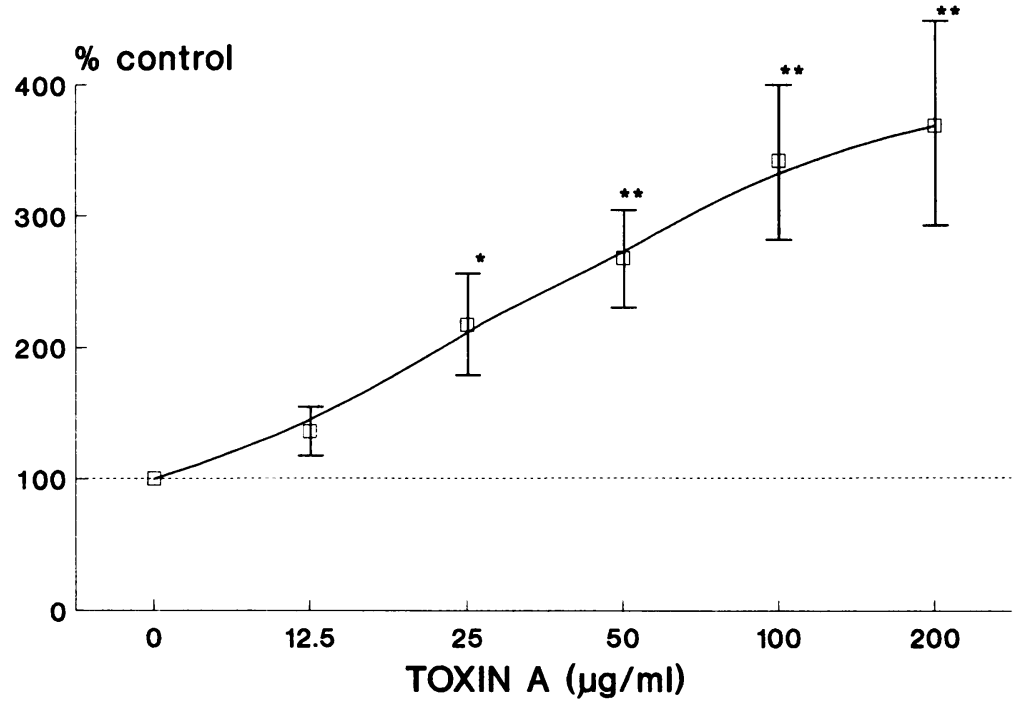

Figure 2. Toxin A-induced neutrophil migration. Migration studies were performed in a multiwell chemotaxis assembly. Rabbit neutrophils $\left(5 \times 10^{6} / \mathrm{ml}\right)$ were placed in the upper chamber, and toxin $A$ at concentrations of $12.5-200 \mu \mathrm{g} / \mathrm{ml}$ in DPBS was placed in the lower chamber for a $1-\mathrm{h}$ incubation at $37^{\circ} \mathrm{C}$. The number of neutrophils migrating into an intervening 3- $\mu \mathrm{m}$ nitrocellulose filter was then counted. Migration of neutrophils to DPBS alone is show by a dotted line, and data are expressed as a percentage of this negative control. Results are shown as means \pm SE. $n$ is $\geq 8$ for each data point. ${ }^{*} P$ $<0.05 ;{ }^{* *} P<0.01$ in comparison with control. manner at concentrations of $25 \mu \mathrm{g} / \mathrm{ml}$ and higher (Fig. 2). The migration induced by toxin $A$ at a concentration of $100 \mu \mathrm{g} / \mathrm{ml}$ was approximately equal to that seen with $10 \mu \mathrm{g} / \mathrm{ml}$ of bacterial endotoxin.

Preincubation of neutrophils with pertussis toxin resulted in $69 \%$ inhibition $(P<0.01)$ of toxin $\mathrm{A}$-induced migration (Fig. 3). As expected, pertussis toxin also inhibited endotoxininduced neutrophil migration (data not shown)(26). Pretreatment with the anti-CD 18 monoclonal antibody $R 15.7$ resulted in almost complete inhibition ( $85 \%, P<0.01$ ) of toxin A-stimulated migration (Fig. 3). The control monoclonal antibody MOPC-21 had no significant effect on toxin A-induced neutrophil migration $(290 \pm 28 \%, n=6)$.

In vivo studies of neutrophil recruitment in toxin A-induced enteritis. The ability of $C$. difficile toxin A to directly stimulate neutrophil migration together with the prominent neutrophil infiltration seen in $C$. difficile enterocolitis led us to examine whether neutrophil recruitment was essential to the in vivo intestinal effects of toxin A. In these experiments, neutrophil recruitment was inhibited using $\mathrm{R} 15.7$, which inhibits neutrophil chemotaxis, adhesion, and tissue infiltration by blocking CD18 (22-24, 27, 28).

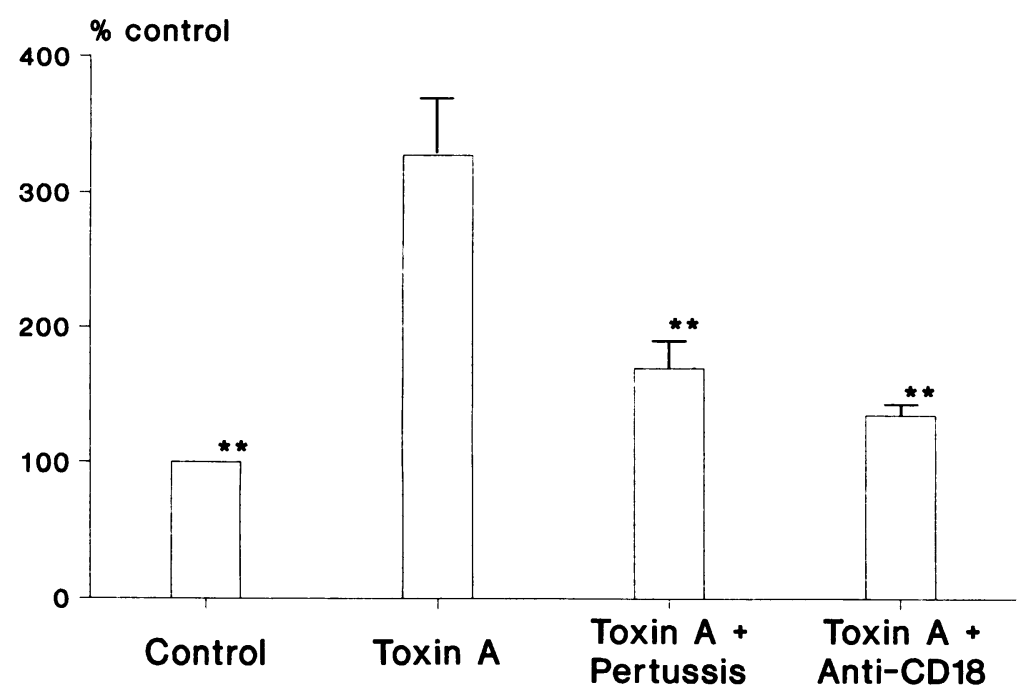

As expected, both toxin A and cholera toxin exhibited potent enterotoxin effects as evidenced by substantial increases in ileal loop weight to length ratios (Fig. 4). Toxin A also induced a dramatic (36-fold) increase in blood to lumen mannitol leakage, indicating increased intestinal mucosal permeability (Fig. 5 ). Cholera toxin induced a lesser (12-fold) increase in mannitol permeability in keeping with previous findings from our laboratory (7). Anti-CD18 substantially reduced both toxin A-induced enterotoxicity (by $65 \%$, Fig. 4 ) and intestinal permeability (by $64 \%$, Fig. 5). In contrast, inhibition of neutrophil adhesion and tissue infiltration with anti-CD18 had no signifcant effect on cholera toxin-associated enterotoxicity (Figs. 4 and 5).

Ileal tissue MPO levels in control loops were $7.6 \pm 1.3 \mathrm{mU} / \mathrm{g}$ ( mean $\pm \mathrm{SE}, n=12$ ). MPO activity was higher in toxin Atreated loops $(10.3 \pm 1.4 \mathrm{mU} / \mathrm{g}, n=11)$, but this increase did not reach statistical significance. MPO levels in toxin A-exposed loops from animals pretreated with $\mathrm{R} 15.7$ were $5.7 \pm 0.7$ $\mathrm{mU} / \mathrm{g}(n=11, P<0.01$ vs toxin A alone), indicating that R15.7 (anti-CD18) effectively inhibited neutrophil infiltration of toxin A-exposed ileal loops.

Histologic examination of ileal tissues from toxin A-ex-
Figure 3. Inhibition of toxin A-induced neutrophil migration by pertussis toxin and by R15.7. Rabbit neutrophils were preincubated with pertussis toxin $(500 \mathrm{ng} / \mathrm{ml}$ for $90 \mathrm{~min}$ at $37^{\circ} \mathrm{C}$ ) or with saturating concentrations of the anti-CD18 monoclonal antibody R15.7 $(50 \mu \mathrm{g} / \mathrm{ml}$ for $60 \mathrm{~min}$ at $37^{\circ} \mathrm{C}$ ) before performing neutrophil migration studies as described in Methods. Toxin A at a concentration of $100 \mu \mathrm{g} / \mathrm{ml}$ was used as chemoattractant. Data are presented as means \pm SE. $n$ is $\geq 15$ for each data point. ${ }^{* *} P<0.01$ in comparison with toxin $\mathrm{A}$ alone. 


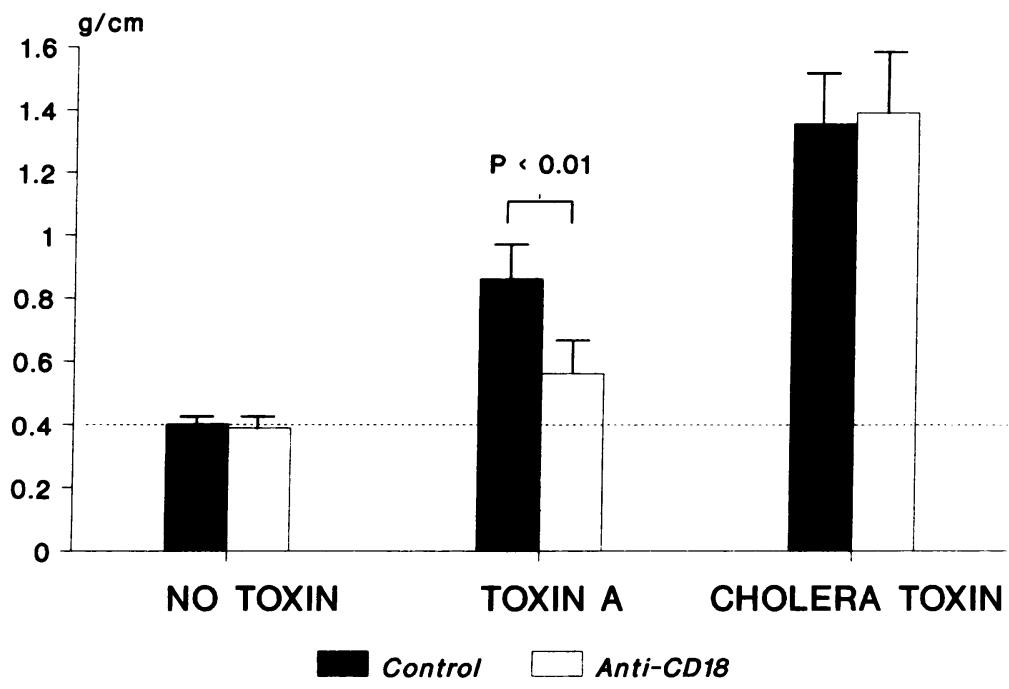

Figure 4. Inhibition of toxin A-induced enterotoxicity by R 15.7. Rabbit ileal loops (7-cm) were injected with $1 \mathrm{ml}$ of Tris buffer alone or with Tris buffer containing $20 \mu \mathrm{g}$ of purified $C$. difficile toxin A or $20 \mu \mathrm{g}$ of $V$. cholera toxin. Test animals were pretreated with the anti-CD18 monoclonal antibody R 15.7 ( $2 \mathrm{mg} / \mathrm{kg}$, i.v.). After $5 \mathrm{~h}$, the ileal loops were harvested, and loop weight to length ratios (grams per centimeter) were measured. The weight to length ratio of the negative control loop is shown by a dotted line. Results are presented as means \pm SE. $n$ is $\geq 9$ for each group. posed loops showed mucosal congestion and edema, neutrophil infiltration, and epithelial damage with disruption of villi (Fig. 6). This histologic damage was markedly reduced by antiCD18 pretreatment (Fig. 6). Histologic scoring of the sections demonstrated that anti-CD18 prevented toxin A-associated neutrophil infiltration of the ileal mucosa (Fig. 7). These findings are in agreement with the data presented above for tissue MPO levels. R15.7 also effected a marked reduction in toxin A-induced mucosal damage (Fig. 7). Indeed, the histologic scores for all three parameters studied (neutrophil infiltration, mucosal congestion and edema, and epithelial damage) were each significantly lower in antibody-treated animals as compared with animals treated with toxin A alone (Fig. 7). However, R15.7 pretreatment did not completely ablate toxin Ainduced epithelial damage; in particular, focal apoptosis of enterocytes was noted at the tips of some villi (Fig. 6). The small amount of congestion and edema identified in controls (Fig. 7) presumably reflects the effects of surgical manipulation and formation of closed ileal loops.

Pretreatment of rabbits with MOPC-21, the murine $\mathrm{IgG}_{1}$ monoclonal control, did not significantly alter the enterotoxic effects of toxin A as measured by increases in loop weight/ length ratio $(1.05 \pm 0.22, n=6)$, mannitol permeability ratio
(39.1 $\pm 19, n=6)$, or histologic scores ( 2.0 for neutrophil infiltration, 2.1 for mucosal congestion and edema, and 2.1 for epithelial damage).

\section{Discussion}

The principal finding of this study is that pretreatment with intravenous $\mathrm{R} 15.7$, a blocking monoclonal antibody to CD18, is associated with marked attenuation of the harmful effects of C. difficile toxin A on rabbit ileum. R15.7 almost completely inhibited $(85 \%)$ toxin $\mathrm{A}$-induced neutrophil migration in vitro and showed similar efficacy in inhibiting neutrophil infiltration of toxin A-exposed ileal loops in vivo as confirmed both by assay for tissue MPO levels and by histologic examination. Inhibition of neutrophil recruitment was accompanied by a marked reduction in toxin A-associated enterotoxicity (by $65 \%$ ) and intestinal mannitol permeability (by 64\%). AntiCD1 8 therapy also resulted in a dramatic attenuation of toxin A-associated mucosal damage as assessed by histology. Taken together, these data provide strong evidence that neutrophilmediated tissue injury plays an important role in the pathogenesis of $C$. difficile toxin A enteritis in the rabbit. These findings may also be of direct relevance to human $C$. difficile colitis

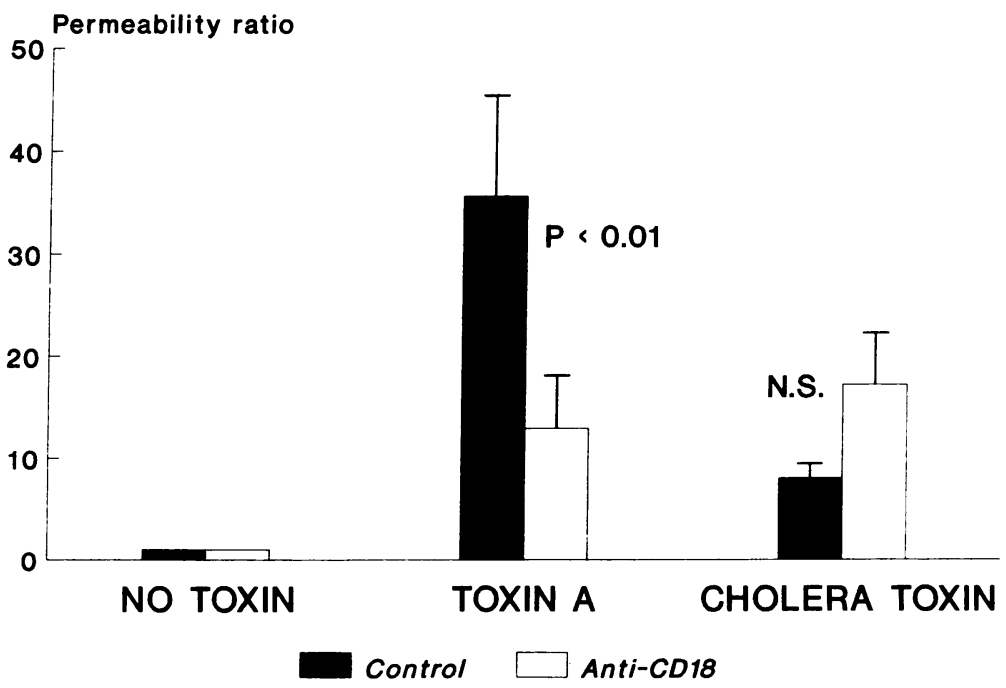

Figure 5. Inhibition of toxin A-induced intestinal mannitol permeability by R15.7. Laparotomy was performed, the renal pedicles were tied, and $\left[{ }^{3} \mathrm{H}\right]$ mannitol $(100 \mu \mathrm{Ci})$ was administered intravenously. Test animals also received the anti-CD18 monoclonal antibody R15.7 (2 $\mathrm{mg} / \mathrm{kg}$, i.v.). Ileal loops $(7 \mathrm{~cm})$ were then formed and were injected with $1 \mathrm{ml}$ of Tris buffer alone or with Tris buffer containing $20 \mu \mathrm{g}$ of purified $C$. difficile toxin A or $20 \mu \mathrm{g}$ of $V$. cholera toxin. After $5 \mathrm{~h}$, the ileal loops were harvested, and total loop mannitol excretion was established by measuring radioactivity in the luminal fluid. Mannitol excretion per centimeter of loop was expressed as a ratio of mannitol excretion per centimeter in a control loop from the same animal. Results are presented as means \pm SE. $n$ is $\geq 8$ for each group. 

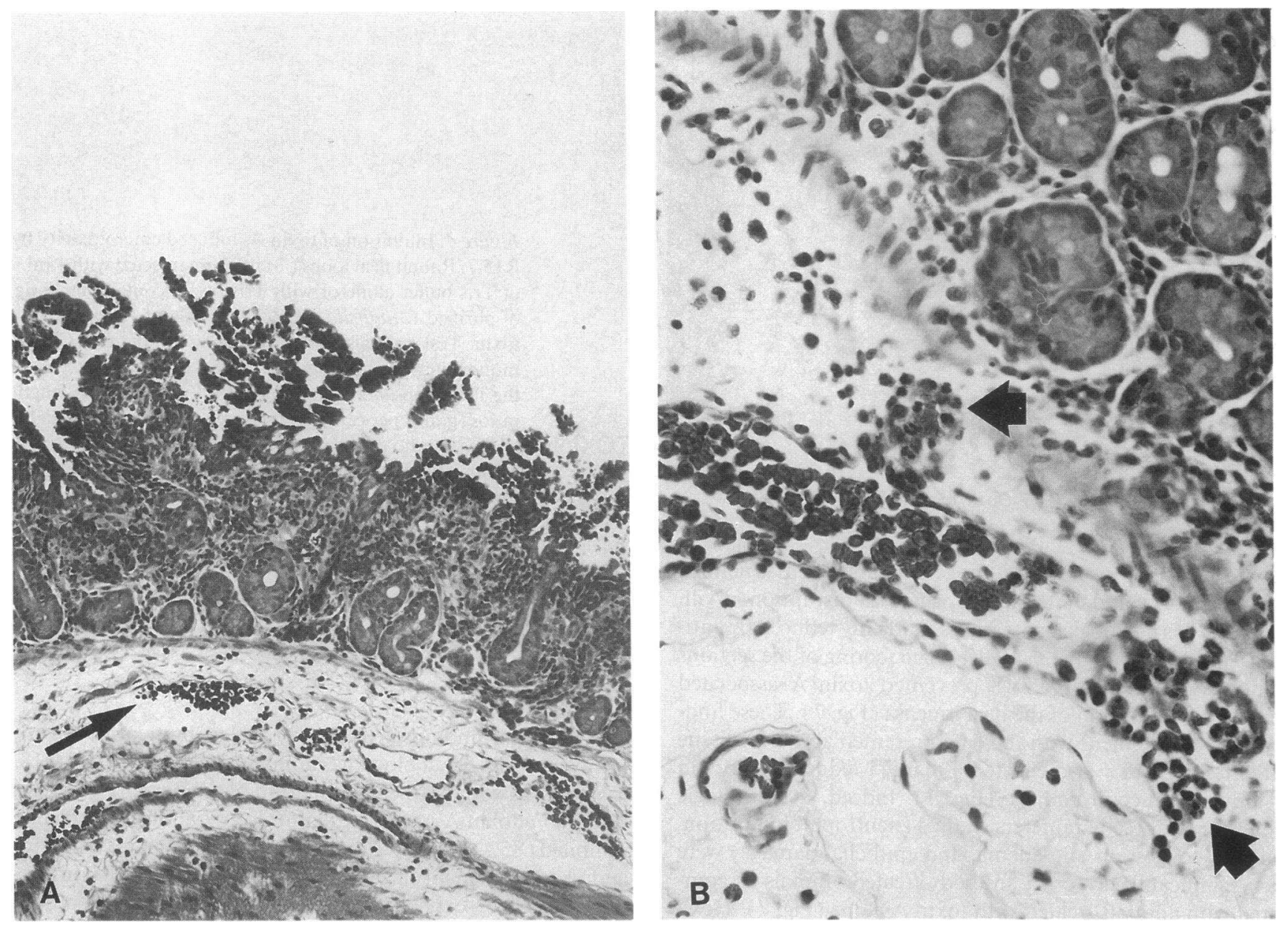

Figure 6. Inhibition of toxin A-induced enteritis by R15.7. Rabbit ileal loops ( $7 \mathrm{~cm}$ ) were formed and were injected with $1 \mathrm{ml}$ of Tris buffer alone or with Tris buffer containing $20 \mu \mathrm{g}$ of purified $C$. difficile toxin A. Test animals were pretreated with the anti-CD18 monoclonal antibody $\mathrm{R} 15.7$ ( $2 \mathrm{mg} / \mathrm{kg}$, i.v.). After $5 \mathrm{~h}$, ileal tissue samples were fixed in formalin, paraffin embedded, and sections were stained with hematoxylin and eosin. $A$ and $B$ are representative photomicrographs of a toxin A-exposed ileal loop taken from a rabbit which was not pretreated with R15.7. $(A)$ There is extensive epithelial damage with almost complete disruption of the villi and the superficial portions of the crypts. Only the crypt bases remain intact. The epithelial destruction is associated with a dense inflammatory infiltrate in the lamina propria. Vascular congestion with neutrophil margination is also evident in submucosal blood vessels (arrow). (B) Higher power view of a submucosal blood vessel with marked vascular congestion and neutrophil margination and extravasation (arrows). $C$ and $D$ are representative photomicrographs of a toxin A-exposed ileal loop from a rabbit pretreated with R15.7. $(C)$ Villous architecture is preserved, there is minimal vascular congestion (arrow), and neutrophil margination and tissue infiltration is not evident. $(D)$ A higher power view of the villus demonstrates that, although villous architecture is largely intact, apoptotic bodies (arrow) representing focal enterocyte damage are evident at the tips of some villi.

where neutrophil infiltration is also a prominent feature (2). In contrast, the enterotoxic effects of cholera toxin in the rabbit model appear to be independent of neutrophil activation and were not affected by anti-CD 18 therapy. These findings are consistent with the different clinical features of $V$. cholera-vs C. difficile-induced diarrheal illnesses in humans $(29,30)$.

Our in vivo studies used a blocking monoclonal antibody directed against the leukocyte surface glycoprotein CD18. The CD11/CD18 family of leukocyte adhesion molecules are heterodimers with at least three distinct alpha subunits (CD1 1a, CD1 lb, and CD1 lc) and a shared beta subunit (beta ${ }_{2}$-integrin or CD18) $(28,31)$. Hereditary deficiency of these adhesion molecules, termed leukocyte adhesion deficiency-1, results in high levels of circulating neutrophils, but a virtual absence of neutrophils at sites of tissue inflammation (32-34). Blocking monoclonal antibodies to $\mathrm{CD} 18$ inhibit neutrophil chemotaxis (23) and adhesion to endothelial cells in vitro (24) and inhibit tissue infiltration by neutrophils in vivo $(35,36)$, essentially recreating the functional neutrophil abnormalities evident in leukocyte adhesion deficiency $(28,32-34)$. Recent animal studies using anti-CD18 antibodies have highlighted the importance of neutrophil infiltration in the pathogenesis of intestinal ischemia-reperfusion injury (35), indomethacin-induced gastritis (36), and the hepatic injury associated with endotoxemia (37). Furthermore, inhibition of leukocyte recruitment and activation by blocking specific cell adhesion molecule interactions represents a novel and potentially useful approach to the treatment of both intestinal and extraintestinal inflammatory disease.

In this study we demonstrate that rabbit neutrophils carry a specific cell-surface receptor for toxin $A$ and present evidence to indicate that this receptor is coupled to a $\mathrm{G}$ protein. We have previously described and characterized the rabbit ileal brush border toxin A receptor (18) which is also G protein-linked 


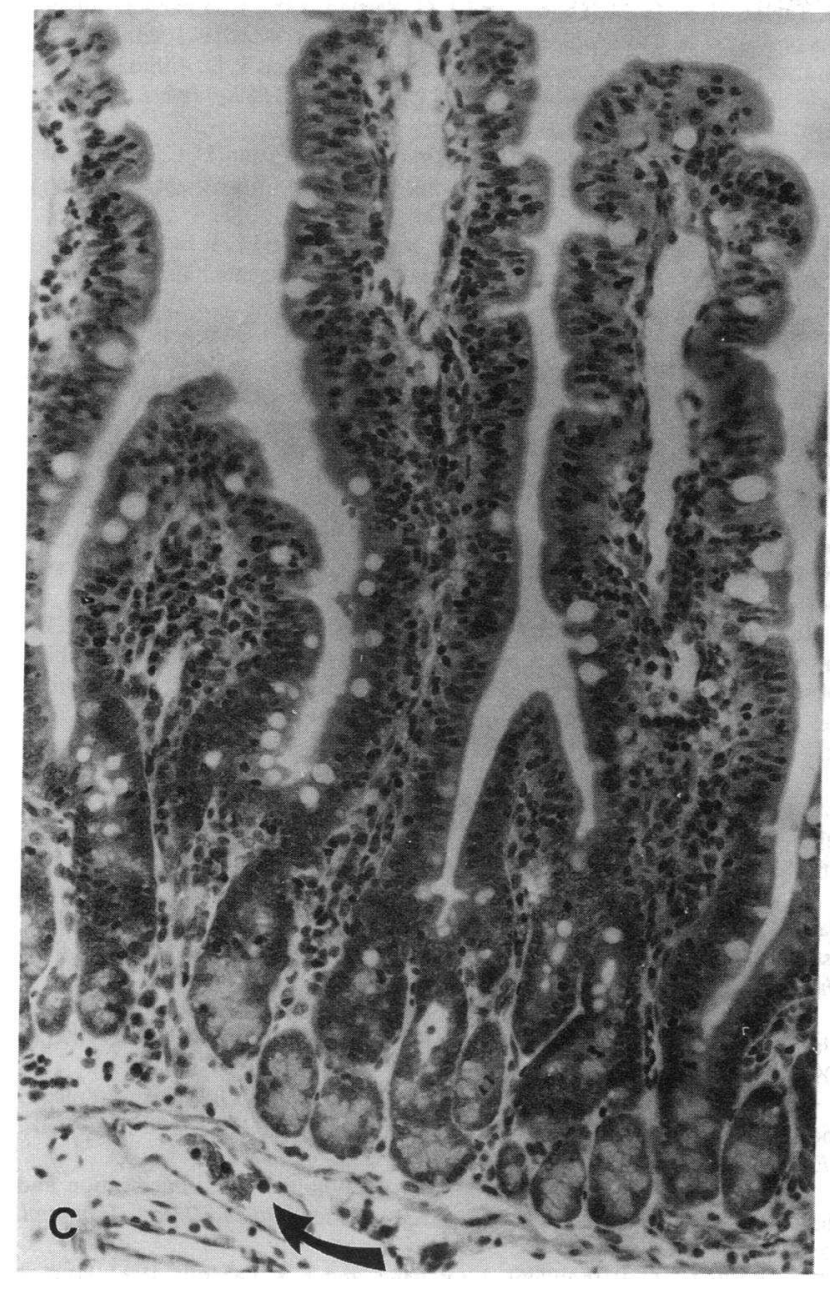

Figure 6 (Continued)

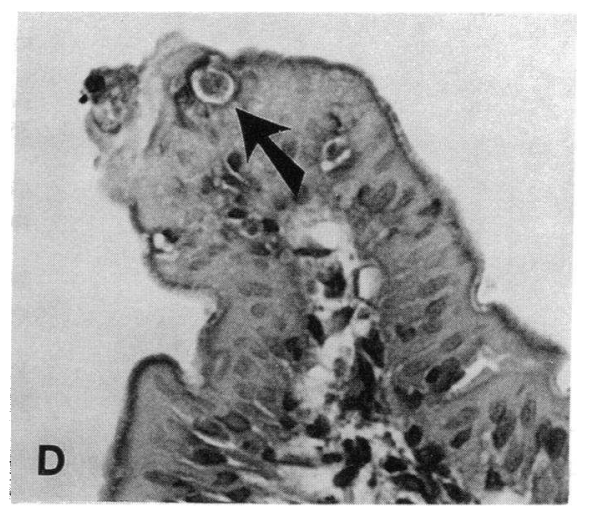

Thus, one possible explanation is that pertussis toxin B subunit has a stimulatory effect on the neutrophil which results in increased toxin A receptor expression while the catalytic subunit reduces receptor affinity through ribosylation of a receptor-associated $G$ protein. Further studies are planned to examine in greater detail the effects of neutrophil activation on toxin A receptor expression and affinity.

It is likely that toxin A is too large ( $308 \mathrm{kD})$ to traverse the intact intestinal epithelium. Although epithelial cell damage was markedly attenuated by pretreatment with $\mathrm{R} 15.7$, some apoptosis of enterocytes, primarily at the villus tip, was still evident (Fig. 7). This is in agreement with the documented cytotoxic effects of toxin A, in particular its ability to disrupt the cytoskeleton, an effect which occurs in vitro in the absence of neutrophils or other inflammatory cells (42). The focal villus damage noted in this study resembles the villus tip injury induced by toxin A on guinea pig ileum mounted in Ussing chambers (43), a system where neutrophil-mediated damage is also largely excluded. Taken together these data suggest that toxin A may exert a direct toxic effect on the intestinal epithelium, particularly the villus tip. The resulting disruption of epithelial integrity may allow toxin A to gain access to and activate inflammatory cells in the subepithelial tissues, resulting in an amplification of its toxic effects.

The findings of this study do not exclude the possibility that neutrophil recruitment by toxin A may be an indirect effect 


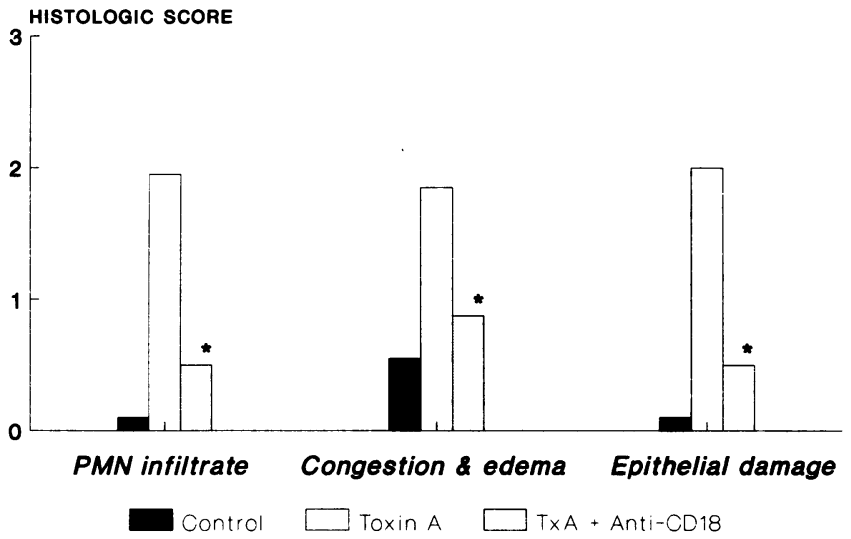

Figure 7. Inhibition of toxin A-induced enteritis by R15.7. Tissue from control and toxin A-exposed rabbit ileal loops were processed as described for Fig. 6 . All sections were examined by a single, blinded, histopathologist ( $\left.\mathrm{JCO}^{\prime} \mathrm{K}\right)$. The histologic severity of enteritis was graded in each section, taking into account the following features: $(a)$ neutrophil margination and tissue infiltration; $(b)$ hemorrhagic congestion and edema of the mucosa; and $(c)$ epithelial cell damage. A score of $0-3$, denoting increasingly severe abnormality, was assigned to each of these parameters. Average histologic grades are presented. $n \geq 8$ for each group. ${ }^{*} P<0.03$ in comparison with toxin $\mathrm{A}$ alone.

mediated, at least in part, through activation of other inflammatory cells resident in the lamina propria and submucosa. We have shown that toxin $\mathrm{A}$ activates macrophages in vitro to release IL-1 (11). Flegel et al. (44) have recently confirmed this finding and have also demonstrated release of other macrophage-derived cytokines, specifically TNFalpha and IL-6. These proinflammatory cytokines, working singly or in concert, may play an important role in mediating neutrophil infiltration of toxin A-exposed intestinal mucosa. For example, both IL-1 and TNFalpha upregulate cell-surface expression of intercellular adhesion molecule- 1 an inducible endothelial cell-surface adhesion receptor for neutrophil CD11a/CD18 and CD1 1 b/CD18 (24, 30). Furthermore, IL-8, another macrophage-derived cytokine, is a potent neutrophil chemotactic factor $(45,46)$. Thus, direct, receptor-mediated stimulation of neutrophil migration may be only one of a number of interrelated mechanisms of neutrophil stimulation and recruitment by toxin A. Nonetheless, our in vivo studies using anti-CD18 monoclonal antibody demonstrate that $C$. difficile toxin $\mathrm{A}$ acts as a proinflammatory enterotoxin whose acute enterotoxic effects are substantially dependent upon neutrophil infiltration.

\section{Acknowledgments}

This study was supported by research grants DK-02128, DK-34583, HL-43161, and HL-05503 from the National Institutes of Health. Dr. Ciaran Kelly held a Career Development Award from The Crohn's and Colitis Foundation of America and is an American Gastroenterological Association/SmithKline Beecham Research Scholar. Dr. Scott Becker was a Crohn's and Colitis Foundation of American Research Fellow.

\section{References}

1. Lylerly, D. M., H. C. Krivan, and T. D. Wilkins. 1988. Clostridium difficile: its disease and toxins. Clin. Microbiol. Rev. 1:1-18.

2. Price, A. B., and D. R. Davies. 1977. Pseudomembranous colitis. J. Clin. Pathol. (Lond.). 30:1-12.
3. Taylor, N. S., G. M. Thorne, and J. G. Bartlett. 1981. Comparison of two toxins produced by Clostridium difficile. Infect. Immun. 34:1036-1043.

4. Lyerly, D. M., D. E. Lockwood, S. H. Richardson, and T. D. Wilkins. 1982. Biological activities of toxins A and B of Clostridium difficile. Infect. Immun. 35:1147-1150.

5. Mitchell, T. J., J. M. Ketley, S. C. Haslam, D. W. Stephen, D. C. Burdon, A. Candy, and R. Daniel. 1986. Effect of toxins A and B on Clostridium difficile on rabbit ileum and colon. Gut. 27:78-85.

6. Triadafilopoulos, G., C. Pothoulakis, M. O'Brien, and J. T. LaMont. 1987. Differential effects of Clostridium difficile toxins A and B on rabbit ileum. Gastroenterology. 93:273-279.

7. Triadafilopoulos, G., C. Pothoulakis, R. Weiss, C. Giampaolo, and J. T. LaMont. 1989. Comparative study of Clostridium difficile toxin A and cholera toxin in rabbit ileum. Gastroenterology. 97:1186-1192.

8. Mathewson, J. J., and H. L. DuPont. 1986. Escherichia coli. In Infectious Diarrhea. S. L., Gorbach, editor. Blackwell Scientific Publications Inc., Boston. 85-90.

9. Pothoulakis, C., R. Sullivan, D. A. Melnick, G. Triadafilopoulos, A.-S. Gadenne, T. Meshulam, and J. T. LaMont. 1988. Clostridium difficile toxin A stimulates intracellular calcium release and chemotactic response in human granulocytes. J. Clin. Invest. 81:1741-1745.

10. Volpi, M., P. H. Naccache, T. F. P. Molski, J. Shefcyk, C.-K. Huang, M. L. Marsh, J. Munoz, E. L. Becker, and R. I. Sha'afi. 1985. Pertussis toxin inhibits f-Met-Leu-Phe but not phorbol ester-stimulated changes in rabbit neutrophils: role of G proteins in excitation response coupling. Proc. Natl. Acad. Sci. USA. 82:2708-2712.

11. Miller, P. D., C. Pothoulakis, T. R. Baeker, J. T. LaMont, and T. L. Rothstein. 1990. Macrophage-dependent stimulation of T cell-depleted spleen cells by Clostridium difficile toxin A and calcium ionophore. Cell. Immunol. 126:155-163.

12. Goldsmith, P., P. Gierschick, G. Milligan, C. G. Unson, R. Vinitsky, H. L. Malech, and A. M. Spiegel. 1987. Antibodies directed against synthetic peptides distinguish between GTP-binding proteins in neutrophil and brain. J. Biol. Chem. 262:14683-14688.

13. Rotrosen, D., J. I. Gallin, A. M. Spiegel, and H. L. Malech. 1988. Subcellular localization of $\mathrm{Gi}$ alpha in human neutrophils. J. Biol. Chem. 263:1095810964.

14. Murphy, P. M., B. Eide, P. Goldsmith, M. Brann, P. Gierschik, A. Spiegel, and H. L. Malech. 1987. Detection of multiple forms of Gi alpha in HL60 cells. FEBS (Fed. Eur. Biochem. Soc.) Lett. 221:81-86.

15. Sullivan, N. M., S. Pellet, and T. D. Wilkins. 1982. Purification and characterization of toxins A and B of Clostridium difficile. Infect. Immunol. 35:1032-1040.

16. Kelly, C., C. Pothoulakis, J. Orellana, and J. T. LaMont. 1992. Human colonic aspirates containing Immunoglobulin A antibody to Clostridium difficile toxin A inhibit toxin A-receptor binding. Gastroenterology. 102:35-40.

17. Pothoulakis, C., L. M. Barone, R. Ely, B. Faris, M. E. Clark, C. Franzblau, and J. T. LaMont. 1986. Purification and properties of Clostridium difficile cytotoxin B. J. Biol. Chem. 261:1316-1321.

18. Pothoulakis, C., J. T. LaMont, R. Eglow, N. Gao, J. B. Rubins, T. C. Theoharides, and B. F. Dickey. 1991. Characterization of rabbit ileal receptors for Clostridium difficile toxin A. Evidence for a receptor-coupled G protein. J. Clin. Invest. 88:119-125.

19. Hirsch, J. G. 1956. Phagocytin. A bactericidal substance from polymorphonuclear leukocytes. J. Exp. Med. 103:589-611.

20. Munson, P. J. 1983. A computerized analysis of ligand binding data. Methods Enzymol. 92:543-576.

21. Maeda, T., K. Balakrishnan, and S. Q. Mehdi. 1983. A simple and rapid method for the preparation of plasma membranes. Biochim. Biophys. Acta. 731:115-120.

22. Entman, M. L., K. Youker, S. B. Shappell, C. Siegel, R. Rothlein, W. J. Dreyer, F. C. Schmalstieg, and C. W. Smith. 1990. Neutrophil adherence to isolated adult canine myocytes. Evidence for a CD18-dependent mechanism. $J$. Clin. Invest. 85:1497-1506.

23. Beatty, P. G., J. A. Ledbetter, P. J. Martin, T. H. Price, and J. A. Hansen. 1983. Definition of a common leukocyte cell-surface antigen (Lp95-150) associated with diverse cell-mediated immune functions. J. Immunol. 131:29132918.

24. Smith, C. W., S. D. Marlin, R. Rothlein, C. Toman, and D. C. Anderson. 1989. Cooperative interactions of LFA-1 and Mac-1 with intercellular adhesion molecule-1 in facilitating adherence and transendothelial migration of human neutrophils in vitro. J. Clin. Invest. 83:2008-2017.

25. Bradley, P. P., D. A. Priebat, R. D. Christensen, and G. Rothstein. 1982. Measurement of cutaneous inflammation: estimation of neutrophil content with an enzyme marker. J. Invest. Dermatol. 78:206-209.

26. Jakway, J. P., and A. L. DeFranco. 1986. Pertussis toxin inhibition of B cell and macrophage responses to bacterial lipopolysaccharide. Science (Wash. DC). 234:743-746.

27. Osborn, L. 1990. Leukocyte adhesion to endothelium in inflammation. Cell. 62:3-6. 
28. Arnaout, M. A. 1990. Structure and function of the leukocyte adhesion molecules CD11/CD18. Blood. 75:1037-1050.

29. Miranda, A. G., and H. L. DuPont. 1991. Small intestine: infections with common bacterial and viral pathogens. In Textbook of Gastroenterology, Volume II. T. Yamada, D. H. Alpers, C. Owyang, D. W. Powell, and F. E. Silverstein, editors. J. B. Lippincott Co., Philadelphia. 1463-1466.

30. LaMont, J. T. 1991. Bacterial infections of the colon. In Textbook of Gastroenterology, Volume II. T. Yamada, D. H. Alpers, C. Owyang, D. W. Powell, and F. E. Silverstein, editors. J. B. Lippincott Co., Philadelphia. 1756-1762.

31. Patarroyo, M., and M. W. Makgoba. 1989. Leukocyte adhesion to cells: molecular basis, physiological relevance, and abnormalities. Scand. J. Immunol. 30:129-164.

32. Crowley, C. A., J. T. Curnutte, R. E. Rosen, J. Andre-Schwartz, J. I. Gallin, M. Klempner, R. Snyderman, F. S. Southwick, T. P. Stossel, and B. M. Baior. 1980. An inherited abnormality of neutrophil adhesion: its genetic transmission and its association with a missing protein. N. Engl. J. Med. 302:11631168.

33. Arnaout, M. A., H. Spits, C. Terhorst, J. Pitt, and R. F. Todd III. 1984. Deficiency of a leukocyte surface glycoprotein (LFA-1) in two patients with Mol deficiency: effects of cell activation on Mol / LFA-1 surface expression in normal and deficient leukocytes. J. Clin. Invest. 74:1291-1300.

34. Anderson, D. C., and T. A. Springer. 1987. Leukocyte adhesion deficiency: an inherited defect in the Mac-1, LFA-1, and p150,95 glycoproteins. Annu. Rev. Med. 38:175-194.

35. Vedder, N. B., R. K. Winn, C. L. Rice, E. Y. Chi, K.-E. Arfors, and J. M. Harlan. 1988. A monoclonal antibody to the adherence-promoting leukocyte glycoprotein, CD18, reduces organ injury and improves survival from hemorrhagic shock and resuscitation in rabbits. J. Clin. Invest. 81:939-944.

36. Wallace, J. L., K.-E. Arfors, and G. W. McKnight. 1991. A monoclonal antibody against the CD18 leukocyte adhesion molecule prevents indomethacininduced gastric damage in the rabbit. Gastroenterology. 100:878-883.

37. Jaeschke, H., A. Farhood, and C. W. Smith. 1991. Neutrophil-induced liver cell injury in endotoxin shock is a CD11b/CD18-dependent mechanism Am. J. Physiol. 261 (Gastrointest. Liver Physiol. 24): G1051-1056.

38. Rosoff, P. M., R. Walker, and L. Winberry. 1987. Pertussis toxin triggers rapid second messenger production in human $\mathrm{T}$ lymphocytes. J. Immunol. 139:2419-2423.

39. Stewart, S. J., V. Prpic, J. A. Johns, F. S. Powers, S. E. Graber, J. T. Forbes, and J. H. Exton. 1989. Bacterial toxins affect early events of T lymphocyte activation. J. Clin. Invest. 83:234-242.

40. Gray, L. S., K. S. Huber, M. C. Gray, E. L. Hewlett, and V. H. Engelhard 1989. Pertussis toxin effects on T lymphocytes are mediated through CD3 and not by pertussis toxin catalyzed modification of a G-protein. J. Immunol. 142:1631-1638.

41. Banga, H. S., R. K. Walker, L. K. Winberry, and S. E. Rittenhouse. 1987. Pertussis toxin can activate human platlets. Comparative effects of holotoxin and its ADP-ribosylating S, subunit. J. Biol. Chem. 262:14871-14874.

42. Hecht, G., C. Pothoulakis, J. T. LaMont, and J. L. Madara. 1988. Clostridium difficile toxin A perturbs cytoskeletal structure and tight junction permeability of cultured human intestinal epithelial monolayers. J. Clin. Invest. 82:15161524.

43. Moore, R., C. Pothoulakis, J. T. LaMont, S. Carlson, and J. L. Madara. 1990. Clostridium difficile toxin A exerts neutrophil-independent effects on intestinal epithelial structure and function. Am. J. Physiol. 259 (Gastrointest. Liver Physiol. 22): G165-G172.

44. Flegel, W. A., F. Muller, W. Daubener, H.-G. Fischer, U. Hadding, and H. Northoff. 1991. Cytokine response by human monocytes to Clostridium difficile toxin A and toxin B. Infect. Immun. 59:3659-3666.

45. Yoshimura, T., K. Matsushima, J. J. Oppenheim, and E. J. Leonard 1987. Neutrophil chemotactic factor produced by lipopolysaccharide(LPS)-stimulated human blood mononuclear leukocytes: partial characterization and separation from interleukin 1 (IL 1). J. Immunol. 139:788-793.

46. Baggiolini, M., A. Walz, and S. L. Kunkel. 1989. Neutrophil-activating peptide-1/interleukin 8 , a novel cytokine that activates neutrophils. J. Clin. Invest. 84:1045-1049. 